LINES IN THE WATER 


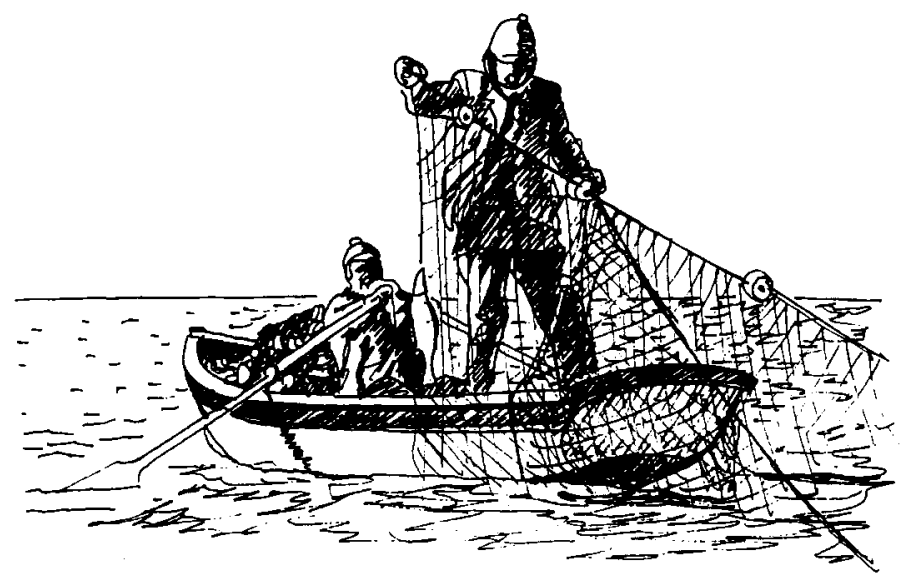




\section{BEN ORLOVE}

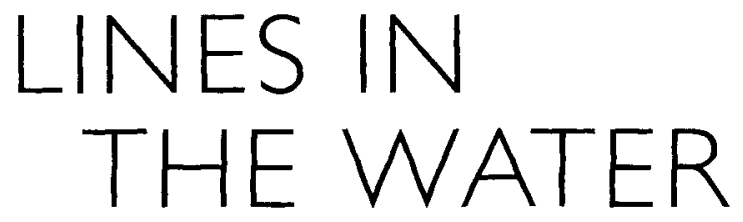

Nature and Culture at Lake Titicaca 
Frontispiece: Drawing of fishermen retrieving gill nets at Lake Titicaca, by Dominique Levieil.

University of California Press

Berkeley and Los Angeles, California

University of California Press, Ltd.

London, England

2002 by

The Regents of the University of California

Library of Congress Cataloging-in-Publication Data

Orlove, Benjamin $\mathrm{S}$.

Lines in the water : nature and culture at Lake Titicaca / Ben Orlove.

p. $\mathrm{cm}$.

Includes index.

ISBN 978-0-520-22959-4 (paper : alk. paper)

1. Titicaca Lake Region (Peru and Bolivia)-Description and travel. 2. Titicaca Lake Region (Peru and Bolivia)-Social life and customs. I. Title.

F3451.P9 0752002

$984 \cdot 12-\mathrm{dc} 21$

2001035872

Manufactured in the United States of America

$\begin{array}{lllll}11 & 10 & 09 & 08 & 07\end{array}$

$\begin{array}{lllllll}10 & 9 & 8 & 7 & 6 & 5 & 4\end{array}$

The paper used in this publication is both acid-free and totally chlorine-free (TCF). It meets the minimum requirements of ANSI/NIsO Z39.48-1992 (R 1997) (Permanence of Paper). $@$ 
Dedicated to

ALBERTO FLORES GALINDO

CÉSAR FONSECA MARTEL

SYLVIA EORMAN

JOHN HYSLOP

IIBBET CRANDON MALAMUD

THIERRY SAIGNES

MICHAEI. SAIL NOW

JOHN TRACEY -

colleagues and friends

who walked the paths of the Andes

and who died too young.

leaving books not witten,

tales not told.

songs not sung. 
This page intentionally left blank 